\title{
Seedling and adult plant resistance to Pyricularia oryzae in Ethiopian rice cultivars
}

\author{
Geleta GEREMA, ${ }^{2 *}$ Girma MENGISTU, ${ }^{1}$ Megersa KEBEDE, ${ }^{2}$ \\ Dagnachew LULE, ${ }^{1}$ Kebede DESALEGN, ${ }^{2}$ \\ Chemeda BIRAHANU, ${ }^{2}$ Megersa DEBELA ${ }^{2}$ \\ ${ }^{1}$ Oromia Agriculture Research Institute, Finfinne, Ethiopia \\ ${ }^{2}$ Bako Agriculture Research Center, Oromia, Ethiopia \\ *Corresponding author: geletarabi@gmail.com
}

Manuscript received: 22 March 2020; revised: 30 March 2020; accepted: 13 April 2020

\begin{abstract}
Two separate experiments were done for seedling and adult resistance in rice varieties against blast. Each experiment consists of 20 varieties and is evaluated under artificial inoculation with blast. The result of the study confirmed that NERICA varieties have shown low disease infection at the seedling stage whereas the varieties Chewaka and Edget have shown adult plant resistance. Severe yield reduction and highly diseased grain were obtained from Superica-1, which is highly susceptible at adult plant stage. In contrast, the maximum grain yield was obtained from the Chewaka and Edget varieties, these having a high level of adult resistance. Therefore, Chewaka and Edget are promising candidates for utilization in yield and blast resistance in rice improvement.
\end{abstract}

Keywords: adult, blast, seedling, susceptible, resistance, rice

\section{Introduction}

Rice (Oryza sativa) is one of the most stable foods providing half of the daily calories for the world's population, including African countries [1, 3]. It is the most important source of carbohydrates, vitamins, minerals, and protein for the developing countries [4-7]. The crop has steadily increased in demand and growing area over the last two decades; thus, it becomes evident that it is a strategic commodity in the food security planning policies of many developing countries [8].

In Ethiopia, rice is one of the new target commodities, whose promotion is emphasized and that has played a significant role in the food security of the 
country [9]. The country has an extensive and suitable ecology for rice production along with the possibility of growing in water-logged areas, where other crops cannot grow. However, the national average yield of rice does not go beyond 2.8 $\mathrm{t}$ ha, which is $37.8 \%$ below the world average yield [10,11]. There are many constraints affecting rice productivity in Ethiopia. Actual productivity and yield stability are highly influenced by biotic factors, including broad and grass weeds and a number of pathogens.

Rice blast is the most devastating pathogen, which causes a significant reduction in grain yield and seed quality [12]. Infection of the blast can occur in any developmental stage of rice, symptoms of the pathogen being mainly found on leave, node, neck, and panicle. Early blast infection can kill seedlings, while and infection occurring at young plant stages results in leaf blast, neck blast, and panicle blast. The blast causes about 10-20\% of yield loss in moderately susceptible varieties, but in severe cases the loss may go up to 80\% [13].

To overcome yield loss due to blast pathogen, making use of host resistance and chemicals are the main strategies applied worldwide, including Ethiopia. The application of fungicides is one of the control measures aimed at minimizing yield loss due to blast disease [14, 15]. However, in developing countries, farmers could not use chemicals prior to the occurrence of the disease. The use of a chemical substance is neither practical nor environmentally friendly [16, 17]. The development of cultivars resistant to blast is considered to be the most effective strategy for protecting rice; this is the cheapest and most effective way of controlling rice blast in the fields of resource-poor farmers [18, 19]. Unfortunately, achieving effective and long-lasting blast resistance is restricted because of breakdowns in resistance due to the occurrence of virulent races [20, 21]. Therefore, considerable effort has been made in developing and identifying blast-resistant varieties with the aim of making low-cost blast management procedures available to farmers.

\section{Materials and methods}

\section{Inoculum preparation}

Isolates were collected from an infected rice variety and then cut into small pieces, containing both the infected and the healthy tissue. Sterilization was done for cut isolates using hypochlorite solution and tap water to eradicate contamination. The cut portions were relocated to oatmeal agar medium and incubated at $25^{\circ} \mathrm{C}$ in a moist chamber for 10 days. Ten days after incubation, the surfaces of the isolated colonies were rubbed gently with a paintbrush. The isolated colonies were exposed under fluorescent light for three to four days to reduce sporulation time. The surface of the Petri-dish containing blast isolates 
was rubbed again with the paintbrush to prepare the conidial suspensions. The conidial suspensions were filtered through filter paper and adjusted to 105 conidia/ml concentration.

\section{Evaluation of seedling resistance}

Twenty rice cultivars were individually planted in the seedling plastic pots containing forest soil and were placed in the lath house. The fertilizer was applied at the rate of $3 \mathrm{gram} / \mathrm{pot}$ in the form of Nitrogen at planting, and 2 grams were applied 5 days after inoculation. When the plants had fully expanded primary leaves, they were inoculated with leaf blast adjusted at the conidial suspension of $10^{5}$ conidia/ml concentration. The inoculated plants were placed in shade until the growth of the lesion started. Reactions of the inoculated plants were evaluated by the visual observation of the type and severity of the lesions present on leaves and in accordance with the diagrammatic scale described by Urashima and Kato [22]. On each plastic pot, the leaf of each five grown seedlings was evaluated.

\section{Resistance for leaf blast at adult stage}

Twenty rice varieties were grown for the assessment of leaf and panicle blast resistance under field conditions. The investigations were carried out at the main station of Bako Agriculture Research Center, Ethiopia, during the main seasons of the 2016-2018 period. Randomized complete block design with three replications was used for the experiments. The fertilizers were applied at the rate of $100 \mathrm{~kg} / \mathrm{ha}$ in the form of phosphorus, and $100 \mathrm{kgha}^{-1}$ Nitrogen were applied: half at planting and the other half 5 days after inoculation. A seed of each genotype was sown in a plot size of $2.5 \mathrm{~m}$ in length, with 6 rows and $20 \mathrm{~cm}$ apart. A seed rate of $20 \mathrm{~g}$ per plot was used for each variety. A susceptible variety, Superica-1, was used as an infector row for both experiments. Inoculation was done at maximum tillering stage for leaf blast evaluation, and heading for panicle blast was adjusted at the conidial suspension of $10^{5}$ conidia/ml concentration. Disease assessment started from the occurrence of the disease and continued for six observations within seven-day intervals for both leaf and panicle blast. Ten plants were randomly selected from each plot and tagged. Disease rating was done for both pathogens on the tagged plant, based on the standard evaluation system for rice [23].

The area under the disease progress curve (AUDPC) is a better indicator of disease expression over time and is used to determine the levels of resistance of rice varieties to blast in field, leaf, and panicle. Blast severity data were converted to areas under disease progress curves (AUDPC) according to the formula described by Shaner and Finney [24-26]. 


$$
\text { AUDPC }=\sum_{i=1}^{n-1} 0.5\left(y_{i+1}+y_{i}\right)\left(t_{i+1}-t_{i}\right)
$$

where $\mathrm{a}=$ total number of observation days, $t_{i}=$ day $I$ (time) expressed as number of days after sowing, $t_{(\mathrm{i}+1)}-t_{i}=$ time (days) between two disease observation dates, and $y_{i}=$ blast severity at $i^{\text {th }}$ observation.

\section{Data analysis}

Data were subjected to statistical analysis using SAS statistical software (version 9.3) to determine the level of significant difference between varieties. The mean separation was done using LSD (0.05) to facilitate the comparison of all pairs of treatment means. The simple linear association between variables like panicle severity, leaf severity, percentage of deteriorated/infected grain, adult plant severity, and seedling stage severity was determined for 20 rice test materials.

\section{Results}

\section{Evaluation of resistance at seedling stage}

Based on seedling evaluation, the varieties tested against Magnaporthe oryzae were grouped into three categories based on a $0-5$ scale as described by Mackill and Bonman [27], i.e. resistant, moderately resistant, and susceptible. The resistant group consists of 6 varieties, which are: Nerica-3, Nerica-12, Nerica-14, Nerica-15, Nerica-18, and Eram-194; this group was found with few types of lesions on some plants. The second group is that of moderate resistance and consists of eleven varieties as follows: Getachew, FOFIFA-3737, FOFIFA3730, Andassa, Tana, Hidassie, Suparica-1, Nerica-4, Nerica-13, Chewaka, and Edget. The third group (susceptible) consists of three varieties: Kokit, FOFIFA4129, and X-Jigna. This group consists of large-sized and a high number of lesions and is characterized by the rapid reproduction of the pathogen (Table 1). 
Table 1. Type of reaction and infection of rice varieties at seedling stage against Pyricularia oryzae in glass house

\begin{tabular}{cccccc}
\hline Varieties & $\begin{array}{c}\text { Type of } \\
\text { infection }\end{array}$ & $\begin{array}{c}\text { Type of } \\
\text { reaction }\end{array}$ & Varieties & $\begin{array}{c}\text { Type of } \\
\text { infection }\end{array}$ & $\begin{array}{c}\text { Type of } \\
\text { reaction }\end{array}$ \\
\hline Suparica-1 & 3 & MR & Nerica-14 & 2 & $\mathrm{R}$ \\
Edget & 3 & MR & Andassa & 3 & MR \\
Nerica-3 & 2 & $\mathrm{R}$ & Nerica-12 & 3 & $\mathrm{R}$ \\
Nerica-4 & 3 & MR & Getachew & 3 & MR \\
Nerica-15 & 2 & $\mathrm{R}$ & Nerica-13 & 3 & $\mathrm{MR}$ \\
Nerica-18 & 2 & $\mathrm{R}$ & FOFIFA-4129 & 4 & $\mathrm{~S}$ \\
Tana & 3 & MR & Eram-194 & 2 & $\mathrm{R}$ \\
Hidassie & 3 & MR & FOFIFA-3737 & 3 & $\mathrm{MR}$ \\
X-Jegna & 4 & $\mathrm{~S}$ & Chewaka & 3 & $\mathrm{MR}$ \\
FOFIFA-3730 & 3 & $\mathrm{MR}$ & Kokit & 4 & $\mathrm{~S}$ \\
\hline
\end{tabular}

Notes: infection types were measured based on a scale of 0.0 to 5.0 (Mackill and Bonman, 1992) $\mathrm{R}=$ resistant, $\mathrm{MR}=$ moderately resistant, and $\mathrm{S}=$ susceptible

\section{Evaluation of resistance for leaf and panicle at adult stage}

Analysis of variance for final leaf and panicle blast severity score (FSC) showed a significant difference in the studied rice cultivars (Table 2). The mean comparison of leaf blast severity (LBS) showed that the Edget and Chewaka varieties had the lowest values with 1.8 and 2.0 rating score, respectively, while, Nerica-3(5), Nerica-4(5), Nerica-14 (5), and Nerica-15(5) had the highest leaf blast severity score (Table 2). Mean comparison of panicle blast severity (PBS) showed that Edget and Chewaka yielded low severity scores with 3.0 and 3.4 score, respectively, while the highest $(\geq 7)$ severity scores were obtained for Nerica-14, Nerica-15, Nerica-4, Nerica-3, and Fofifa-3037 (Table 2).

The ANOVA obtained from the estimated areas under disease progress curves (AUDPC) for both leaf and panicle blast significantly varied in the studied rice varieties (Table 2). The highest estimated AUDPC value for leaf blast was recorded for Nerica-14 (533.3), followed by Nerica-15 (523.0) and Superica-1 (520.0), while the lowest values were obtained for Edget (266.6) and Chewaka (380.0). Similarly, the maximum mean value of AUDPC from panicle blast was obtained for Nerica-14 (1861.9) and Superica-1 (1823.8), whereas the lowest values were obtained for Edget (895.2) and Chewaka (955.2) (Table 2).

The analysis of variance for grain yield showed significant $(\mathrm{P}<0.05)$ differences among the varieties (Table 2). The highest grain yield was obtained for Chewaka (4213.3 $\left.\mathrm{kg} \mathrm{ha}^{-1}\right)$, followed by the Edget $\left(2625.3 \mathrm{~kg} \mathrm{ha}^{-1}\right)$ variety, 
both varieties showing high levels of adult resistance to both leaf and panicle blast. In contrast, low yield was obtained for Nerica-14 (202.7 kg ha-1), followed by Superica-1-1 $\left(606.0 \mathrm{~kg} \mathrm{ha}^{-1}\right)$, which were susceptible to both pathogens and highly susceptible to panicle blast (Table 2).

Table 2. Infection type (leaf blast), panicle blast severity, area under the disease progress curve (AUDPC), leaf and panicle blast, and grain yield for rice varieties in field conditions

\begin{tabular}{|c|c|c|c|c|c|c|c|}
\hline \multirow{2}{*}{ Varieties } & \multicolumn{2}{|c|}{$\begin{array}{l}\text { Area under progress } \\
\text { curve (AUDPC) }\end{array}$} & \multirow{2}{*}{$\begin{array}{c}\text { FLBS } \\
(1-5 \\
\text { scale })\end{array}$} & \multirow{2}{*}{$\begin{array}{l}\text { Host } \\
\text { response } \\
\text { to leaf } \\
\text { blast }\end{array}$} & \multirow{2}{*}{$\begin{array}{c}\text { FPBS } \\
(1-9 \\
\text { scale })\end{array}$} & \multirow{2}{*}{$\begin{array}{c}\text { Host } \\
\text { response } \\
\text { to panicle } \\
\text { blast }\end{array}$} & \multirow{2}{*}{$\begin{array}{c}\text { Grain } \\
\text { yield } \\
(\mathrm{Kg} / \mathrm{ha})\end{array}$} \\
\hline & leaf blast & panicle blast & & & & & \\
\hline Nerica-14 & $533.3 \mathrm{a}$ & $1861.9 \mathrm{a}$ & $5.0 \mathrm{a}$ & $\mathrm{S}$ & $7.8 \mathrm{a}$ & $\mathrm{S}$ & $202.7 \mathrm{fe}$ \\
\hline Superica-1 & $520.0 \mathrm{a}$ & $1823.8 \mathrm{ba}$ & $4.9 \mathrm{ba}$ & S & $6.6 \mathrm{bac}$ & S & $660.0 \mathrm{dfe}$ \\
\hline Xchegna & $516.3 \mathrm{a}$ & $1819.0 \mathrm{ba}$ & $4.7 \mathrm{ba}$ & $S$ & $7.0 \mathrm{ba}$ & S & 1172.0dfe \\
\hline Nerica-15 & $523.0 \mathrm{a}$ & $1795.2 \mathrm{ba}$ & $5.0 \mathrm{a}$ & S & $7.5 \mathrm{a}$ & S & $272.0 \mathrm{fe}$ \\
\hline Nerica-3 & $506.6 \mathrm{ba}$ & $1790.5 \mathrm{ba}$ & $5.0 \mathrm{a}$ & $S$ & $7.3 \mathrm{ba}$ & S & $1233.3 \mathrm{dfe}$ \\
\hline Andassa & $514.3 \mathrm{a}$ & $1781.0 \mathrm{ba}$ & 4.6bac & $S$ & $7.0 \mathrm{ba}$ & S & $1792.0 \mathrm{dc}$ \\
\hline Tana & $500.0 \mathrm{ba}$ & $1780.9 \mathrm{ba}$ & $4.5 \mathrm{bac}$ & $S$ & $6.6 \mathrm{bac}$ & S & 1441.3dce \\
\hline FOFIFA-3037 & $505.6 \mathrm{ba}$ & $1776.2 \mathrm{ba}$ & $4.8 \mathrm{ba}$ & S & $7.2 \mathrm{ba}$ & S & 1316.0dfe \\
\hline Nerica-4 & $521.0 \mathrm{a}$ & $1771.4 \mathrm{ba}$ & $5.0 \mathrm{a}$ & S & $7.4 \mathrm{ba}$ & S & $682.7 \mathrm{dfe}$ \\
\hline Nerica-12 & $506.6 \mathrm{ba}$ & $1757.2 \mathrm{ba}$ & $4.8 \mathrm{ba}$ & $S$ & $6.6 \mathrm{bac}$ & S & $827.3 \mathrm{dfe}$ \\
\hline FOFIFA-3737 & $500.0 \mathrm{ba}$ & $1757.1 \mathrm{ba}$ & $4.9 \mathrm{ba}$ & $S$ & $6.3 \mathrm{bac}$ & S & 931dfe \\
\hline Getachew & $5003.0 \mathrm{ba}$ & $1733.3 \mathrm{ba}$ & 4.6bac & $S$ & $6.3 \mathrm{bac}$ & $\mathrm{S}$ & $920.3 \mathrm{dfe}$ \\
\hline Hiddasie & $502.0 \mathrm{ba}$ & $1704.8 \mathrm{bac}$ & $3.6 \mathrm{bdc}$ & MR & $5.0 \mathrm{bc}$ & MR & 1000.0dfe \\
\hline Nerica-18 & $473.3 \mathrm{bac}$ & $1604.8 \mathrm{bac}$ & $4.3 \mathrm{bac}$ & $\mathrm{S}$ & $6.0 \mathrm{bac}$ & $\mathrm{S}$ & $102.7 f$ \\
\hline Nerica-13 & $466.6 \mathrm{bac}$ & $1585.7 \mathrm{bac}$ & $4.7 \mathrm{bac}$ & $\mathrm{S}$ & $5.0 \mathrm{bc}$ & MR & $340.0 \mathrm{fe}$ \\
\hline Koki & $440.0 \mathrm{bac}$ & $1571.4 \mathrm{bac}$ & $3.8 \mathrm{bdc}$ & MR & $4.4 b c$ & MR & $1753.3 \mathrm{dc}$ \\
\hline Eram-194 & 446.6bac & $1571.4 \mathrm{bac}$ & $4.7 \mathrm{bac}$ & $\mathrm{S}$ & $6.2 \mathrm{bac}$ & $\mathrm{S}$ & $1108.0 \mathrm{dfe}$ \\
\hline FOFIFA-4129 & $440.0 \mathrm{bac}$ & $1557.1 \mathrm{bac}$ & $4.0 \mathrm{bdc}$ & $\mathrm{R}$ & $6.5 \mathrm{bac}$ & S & 801.3dfe \\
\hline Chewaka & $380.0 \mathrm{dc}$ & $955.2 \mathrm{~d}$ & $2.0 \mathrm{~d}$ & $\mathrm{R}$ & $3.4 \mathrm{~d}$ & $\mathrm{R}$ & $4213.0 \mathrm{a}$ \\
\hline Edget & $266.6 \mathrm{~d}$ & $895.2 d$ & $1.8 \mathrm{~d}$ & $\mathrm{R}$ & $3.0 \mathrm{~d}$ & $\mathrm{R}$ & $2625.3 b c$ \\
\hline Lsd & 118 & 361 & 1.08 & & 1.6 & & 1279.5 \\
\hline $\mathrm{CV}$ & 15.1 & 13.2 & 14.3 & & 12.2 & & 15 \\
\hline F-test & 0.01 & 0.001 & 0.01 & & 0.004 & & 0.002 \\
\hline
\end{tabular}

Notes: Means followed by the same letter within the column are not significantly different at $5 \%$ probability level. $\mathrm{LSD}=$ least significant difference, $\mathrm{CV}=$ coefficient of variation, $\mathrm{P}=$ probability, $* *=$ highly significant $(\mathrm{p}<0.01), *=$ significant $(\mathrm{p}<0.05), \mathrm{ns}=$ non-significant, FLBS $=$ final leaf blast severity, FPBS = final panicle blast severity, $\mathrm{R}=$ resistant, $\mathrm{MR}=$ moderately resistant, and $\mathrm{S}=$ susceptible. 


\section{Rice grain deterioration due to panicle blast}

Results of the study revealed that the grains of Chewaka and Edget were less deteriorated compared with Nerica and other tested varieties (Fig. 1). Significantly lowest percentage of infected/deteriorated grains was obtained for Chewaka (20.4\%) and Edget (21\%), whereas the highest percentage of infected grains was recorded for NERICA varieties (Fig. 1).

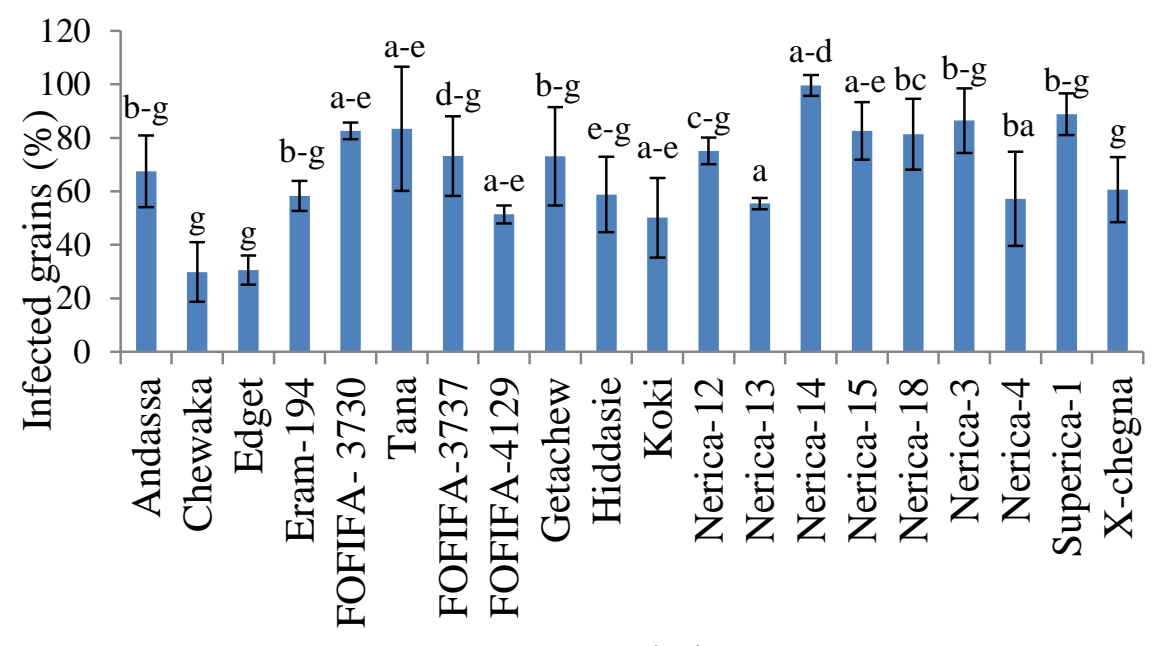

Varieties

Figure 1. Percentage of infected grains for 20 rice varieties due to panicle blast

\section{Analysis of correlation coefficient}

The simple linear association between variables, such as severity scale due to leaf blast at seedling and adult plant stage, area under disease progress curve for leaf and panicle blast, or percentage of deteriorated grain due to panicle blast, were determined for 20 rice cultivars (figures 2-5). The percentage of affected (diseased) grains was significant and was found in positive correlation with the final severity score of panicle blast $(\mathrm{r}=0.64, \mathrm{P} \leq 0.05)$ (Figure 2$)$. The final severity score of leaf blast had a negative and non-significant association with severity score at seedling stage $(\mathrm{r}=-0.38, \mathrm{P} \leq 0.05)$ (Figure 3$)$. Panicle severities were negative and highly significantly correlated with diseased grain $(r=-0.77$, $\mathrm{P}<0.01)$. The estimated AUDPC from leaf blast had a positive and highly significant correlation with AUDPC calculated for panicle blast $(\mathrm{r}=0.908$, $\mathrm{P} \leq 0.01)$ (Figure 5). 


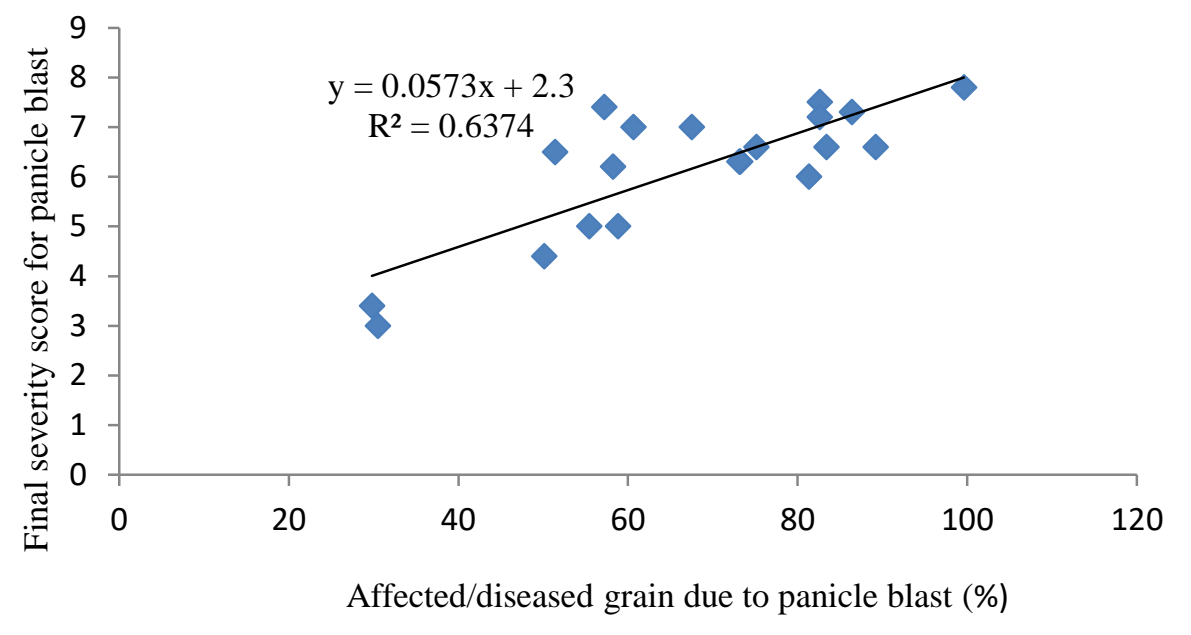

Figure 2. Correlation between the percentage of diseased/infected grain and panicle blast for 20 rice varieties (significant by student's t-test at $5 \%$ probability)

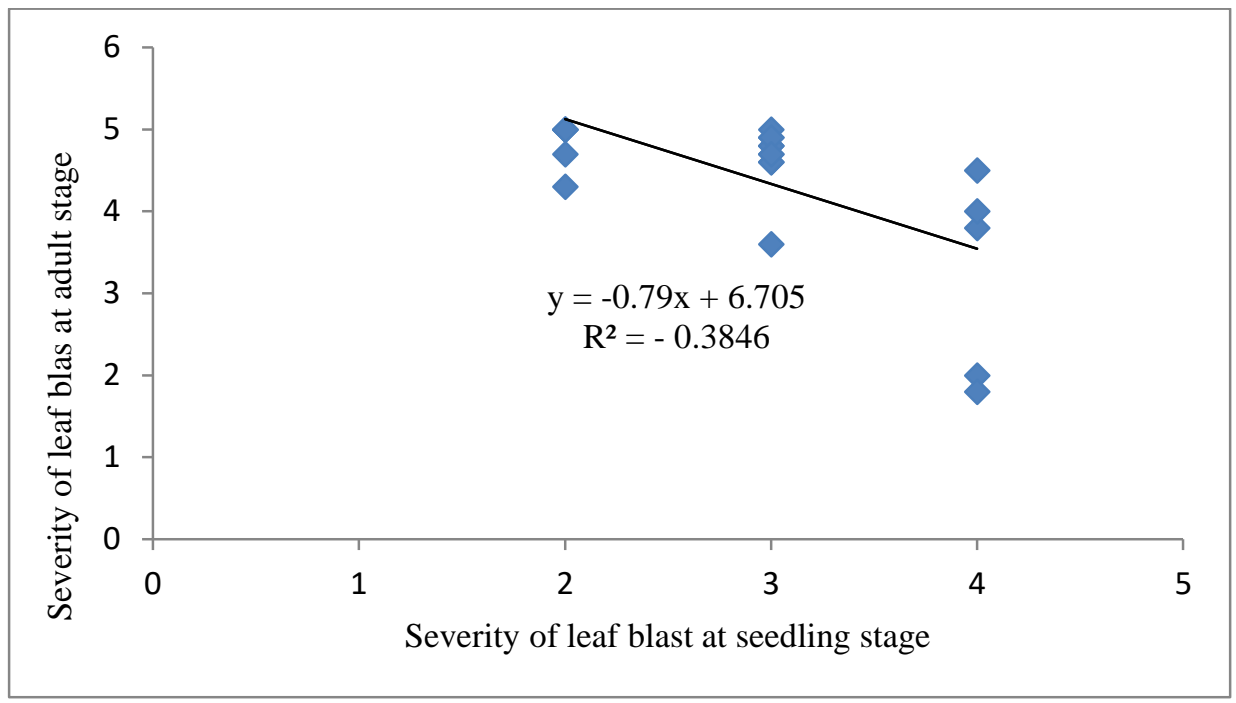

Figure 3. Correlation between blast infection at seedling and adult plant stage for 20 rice varieties (non-significant by student's t-test at $5 \%$ probability) 


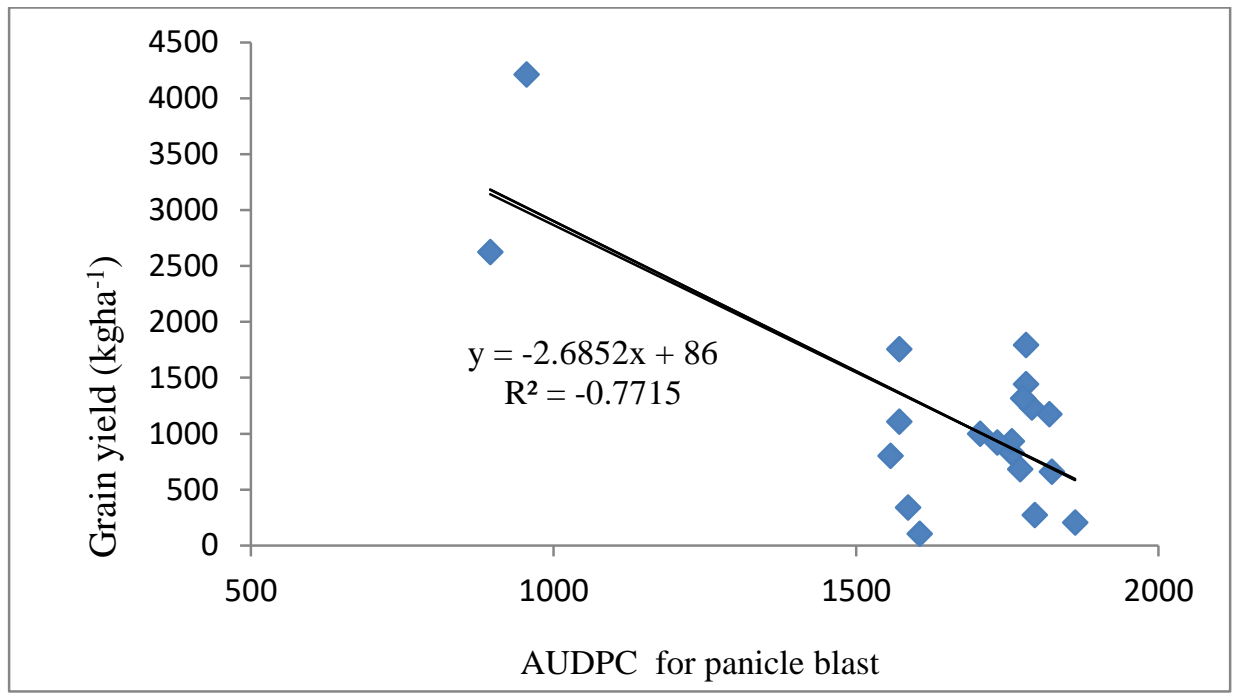

Figure 4. Correlation between AUDPC and grain yield for 20 Rice varieties (significant by student's t-test at $5 \%$ probability)

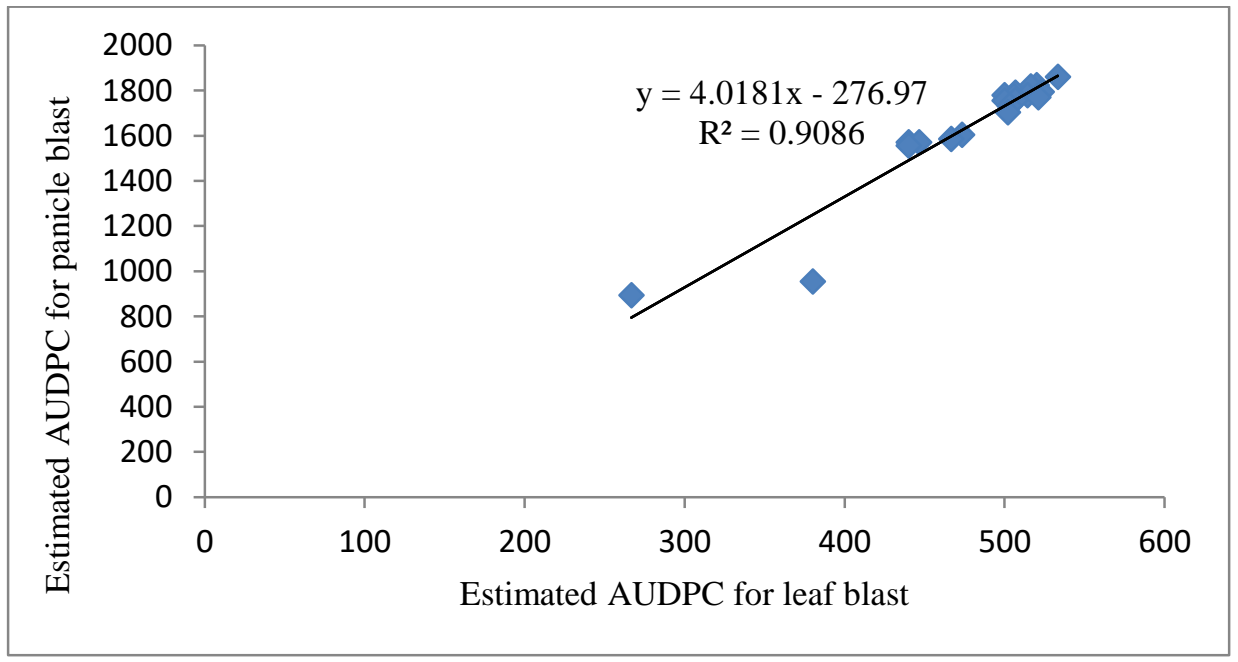

Figure 5. Correlation between AUDPC and panicle blast for 20 rice varieties (significant by student's t-test at $5 \%$ probability) 


\section{Discussion}

Evaluation results of seedling resistance in rice varieties to Pyricularia oryzae revealed that NERICA-3, NERICA-12, NERICA-14, NERICA-15, NERICA-18, and Eram-194 showed low infection types (ITs "1"-“2") based on a 0-5 scale as described by Mackill and Bonman [27]. These varieties yielded small numbers of sporulation lesions and reduced spore reproduction, suggesting that they may have complete resistance genes against blast. Complete resistance minimizes the entrance of the pathogen through developing anti-pathogen by the plant and reduces spore reproduction and sporulation lesions [28-29]. This interaction is under a gene-for-gene control [30]. Getachew, FOFIFA 3737, FOFIFA 3730, Andassa, Tana, Hidassie, Superica-1, Nerica-4, Nerica-13, Chewaka, and Edget varieties showed moderate infection types, while Kokit, FOFIFA 4129, and X-Jigna showed high infection types (susceptible reaction) (ITs "4"-“5") against blast at seedling stage. Thus, these varieties showed low levels of resistance at seedling stage.

The field evaluation for adult plants indicated that NERICA 3, NERICA 4, NERICA 12, NERICA 14, NERICA 15, and NERICA 18 had low levels of resistance to leaf and panicle blast, while Chewaka and Edget had the lowest infection rate and AUDPC value for both types of blast, which showed a high level of resistance to leaf and panicle blast. This indicates an increase in blast severity corresponding with an increased area under the disease progress curve. The Chewaka and Edget varieties showed a slow development of lesions, low disease pressure, and fewer as well as smaller blast lesions, which reduce the extent of pathogen reproduction in the compatible interaction. These suggestions are in agreement with Bonman [31] and Elsa [32], who reported the nature of partial resistance, the compatible lesion types but also the low level of disease pressure and fewer and smaller blast lesions than with fully susceptible cultivars and that spore production may be reduced.

These findings confirmed that Chewaka and Edget had moderate blast infection at seedling stage compared with lower ones (2.8-3.0) at adult stage. Some contend that seedling resistance is effective at all growth stages, while some others argue that resistance is effective at adult or seedling growth stages only [33]. Results of linear relationship imply that rice blast infection at seedling stage is negative and is non-significantly correlated with adult stage $(\mathrm{r}=-0.38, \mathrm{P}<$ 0.05). According to Qi [34], increase in resistance with increase in growth stage might be due to: morphological and physiological differences in leaf tissues, latent period-prolonging genes may not be expressed in seedling stage but are better expressed in adult plant stage. Koizumi et al. [35] reported similar results.

Results of the study indicated differences in yield reduction among rice cultivars that were dependent on leaf and panicle blast development. The highest 
yield reduction occurred in the variety Superica-1, which is highly susceptible to both leaf and panicle blast, while Chewaka and Edget had high levels of adult resistance to both leaf and panicle blast. Similarly, Sim et al. [36] and Charles [37] reported that severe yield reduction was caused by severe leaf and panicle blast, including neck rot, resulting in complete yield loss. Rice blast disease severity for panicle was found positive and highly significantly correlated with grain yield reduction. This indicates that panicle blast disease severity was directly related to grain yield losses. The finding that an increase in leaf or panicle blast disease severity corresponds with an increase in grain yield losses has also been reported by Shim et al. [38] and Charles [37].

Severe infection of rice panicle by Pyricularia oryzae has also been considered a major cause of reducing the grain quality of rice by reducing the percentage of ripe spikelets and the percentage of fully mature grains $[12,36,38]$. This suggestion supports the current studies that grains of the varieties susceptible to panicle blast, such as Nerica-14, Nerica-13, Nerica-15, and Nerica-18, were highly affected due to panicle blast. The lowest percentage of diseased grain was obtained for Chewaka and Edget. The relationship between panicle blast disease severity and the percentage of diseased/affected grains indicated that an increase in disease severity resulted in a simultaneous increase in the diseased/affected grain. Panicle severities were positive and significantly correlated with diseased grains.

\section{Conclusions}

In conclusion, the rice varieties Chewaka and Edget were recorded to have superior grain yield, had effects on the reduction of disease development rate and the lower number and size of blast spots on the leaves/panicle, and minimized grain deterioration. Therefore, these two varieties are promising solutions, which could be utilized in yield and blast resistance breeding programmes in western Ethiopia.

\section{References}

[1] Abbas, A., Murtaza, S., Aslam, F., Khawar, A., Rafique, S., Naheed, S. (2011), Effect of processing on nutritional value of rice (Oryza sativa). World J. Med. Sci. 6, 68-73.

[2] Jaisut, D., Prachayawarakorn, S., Varanyanond, W., Tungtrakul, P., Soponronnarit, S. (2008), Effects of drying temperature and tempering time on starch digestibility of brown fragrant rice. J. F. Eng. 86, 251-258.

[3] Pishgar-Komleh, S. H., Sefeedpari, P., Rafiee, S. (2011), Energy and economic analysis of rice production under different farm levels in Guilan province of Iran. Ene. 36, 5824-5831.

[4] Iqbal, S., Bhanger, M. I., Anwar, F. (2005), Antioxidant properties and components of some commercially available varieties of rice bran in Pakistan. Food Chem. 93(2), 265-272. 
[5] Liu, Q. (2005), Understanding starches and their role in foods. In: Cui, S. W. (ed.), Food carbohydrates: Chemistry, physical properties and applications. CRC Press: Boca Raton. 309-355.

[6] Schramm, R., Abadie, A., Hua, N., Xu, Z., Lima, M. (2007), Fractionation of the rice bran layer and quantification of vitamin $\mathrm{E}$, oryzanol, protein, and rice bran saccharide. J. Biol. Eng. 1, 1-9.

[7] Mahender, A., Anandan, A., Pradhan, S. K. (2016), Rice grain nutritional traits and their enhancement using relevant genes and QTLs through advanced approaches. Springerplus 5, 2086.

[8] FAO. (2003), Rice development strategies for food security in Africa. Proceedings of the $20^{\text {th }}$ Session of the International Rice Commission. Bangkok, Thailand, 23-26 July 2002.

[9] Mesfin, A. H., Zemedu, L. (2018), Choices of varieties and demand for improved rice seed in Fogera district of Ethiopia. Ric. Sci. 25(6), 350-356.

[10] CSA. (2017), Agricultural sample survey: Area and production of major crops, meher season for Private Peasant Holdings. Addis Ababa, Ethiopia.

[11] FAO. (2017), Rice Market Monitor (RMM) provides an analysis of the most recent developments in the global rice market, including a short-term outlook.

[12] Asadollah, A., Vahid, K. (2018), Rice grain quality as affected by blast-causing agent (Pyricularia oryzae) along with a molecular analysis of blast resistance at Pi5 and Pi-ta loci. A.J.C.S. 12(06), 870-877.

[13] Manandha, H. K., Shrestha, K., Amatya, P. (1992), Seed-borne diseases. In: Mathur, S. B., Amatya, P., Shrestha, K., Manandhar, H. K. (eds.), Plant diseases, seed production and seed health testing in Nepal. Danish Government, Institute of Seed Pathology for Developing Countries, Copenhagen, Denmark. 59-74.

[14] Skamnioti, P., Gurr, S. J. (2015), Against the grain: Safeguarding rice from rice blast disease. Trends in Biotechnology 27(3), 141-150.

[15] Debashis, D., Supradip, S., Prasad, R. D., Bag, M. K. (2012), Effect of different active fungicides molecules on the management of rice blast disease. Int. J. Agric. Environ. Biotechnol. 5 (3), 247-251.

[16] Burgess, D. R., Keane, P. J. (1997), Biological control of Botrytis cinerea on chickpea seed with Trichoderma spp. and Gliocladiumroseum: Indigenous versus non-indigenous isolates. Plant. Pathol. 46, 910-918.

[17] Birgit, J. I., Knudsen, M. B., Dan Funck, J. (2000), Biological seed treatment of cereals with fresh and long-term stored formulations of Clonostachysrosea: Biocontrol efficacy against Fusarium culmorum. Eur. J. Plant. Pathol. (106), 233-242.

[18] Séré, Y., Sy, A. A., Siré, M., Onasanya, A., Akatora, S. K., Kabore, B., Conde, C. K., Traore, M., Kiepe, P. (2011), Importance of varietal improvement for blast disease control in Africa. J.I.R.C.A.S. 70, 77-90.

[19] Khan, M., Ali, M., Monsur, M., Kawasaki-Tanaka, A., Hayashi, N., Yanagihara, S., Obara, M., Mia, M., Latif, M., Fukuta, Y. (2016), Diversity and distribution of rice blast (Pyricularia oryzae Cavara) races in Bangladesh. Plant. Dis. 100, 2025-2033.

[20] Zhou, E., Jia, Y., Singh, P., Correll, J. C., Lee, F. L. (2007), Instability of the Magnaporthe oryzaea virulence gene AVR-Pita alters virulence. Fungal. Genet. Biol. 44, 1024-1034.

[21] Koizumi, S. (2007), Durability of resistance to rice blast disease. In: Fukuta, Y., Vera, C. M., Kobayashi, N. (eds.), A differential system for blast resistance for stable rice production environment. J. I. R. C. A. S. Working Report 53.

[22] IRRI. (2002), Standard evaluation system for rice. International Rice Research Institute, Los Banos, Manila, Philippines.

[23] Urashima, A. S., Kato, H. (1994), Varietal resistance and chemical control of wheat blast fungus. Summa Phytopathologica 20, 107-112. 
[24] van der Plank, J. E. (1963), Plant diseases: Epidemics and control. New York: Academic Press.

[25] Chaurasia, S., Joshi, A. K., Dhari, R., Chand, R. (1999), Resistance to foliar blight of wheat. Genet. Res. Crop. Evol. 46, 469-475.

[26] Shaner, G., Finney, R. E. (1977), The effect of nitrogen fertilization on the expression of slow-mildewing resistance in Knox wheat. Phytopathology 67, 1051-1056.

[27] Mackill, D. J., Bonman, J. M. (1992), Inheritance of blast resistance in near-isogenic lines of rice. Phytopathology 82, 746-749.

[28] Gallet, R., Bonnot, F., Milazzo, J., Tertois, C., Adreit, H., Ravigné, V., Fournier, E. (2014), The variety mixture strategy assessed in a $\mathrm{G} \times \mathrm{G}$ experiment with rice and the blast fungus Magnaporthe oryzae. Front. Gen. 4, 312.

[29] Ribeirodo Vale, F. X., Parlevliet, I. E., Zambolim, I. (2001), Concepts in plant disease resistance. Fitopatologia Brasileira 26577-26589.

[30] Jones, J. D. G., Dangl, J. L. (2006), The plant immune system. Nature 444, 323-329.

[31] Bonman, J. M., Estrada, B. A., Kim, C. K., Lee, E. J. (1991), Assessment of blast disease and yield loss in susceptible and partially resistant rice cultivars in two irrigated lowland environments. Plant. Dis. 75, 462-466.

[32] Elsa, B., Jean-Benoît, M., Gaétan, D., Adam, P., Brigitte, C., Jean-Loup, N., Didier, T. (2008), Agenome-wide meta-analysis of rice blast resistance genes and quantitative trait loci provides new insights into partial and complete resistance. M.P.M.I. 21, 859-868.

[33] Amin, K. P., Robert, F. P. (2006), Evaluation of seedling and adult plant resistance to leaf rust in European wheat cultivars. Euphy. 149, 327-342.

[34] Qi, X., Niks, R. E., Stam, P., Lindhout, P. (1998), Identification of partial resistance to leaf rust (Puccinia hordei) in barley. Theor. Appld. Genet. 96, 1205-1215.

[35] Koizumi, S., Zenbayashi, K., Ashizawa, T., Hayashi, N. (2000), Conditions necessary for simple evaluation of field resistance to panicle blast in rice cultivars using spray-inoculated cut panicles. Ann. Rept. Plant Prot. North Japan 51, 18-22.

[36] Sim, Hong-Sik, Hong, Sung-Jun, Han, Seong-Suk. (2005), Damage analysis of rice panicle blast on disease occurrence time and severity. Plant. Path. J. 21(2), 87-92.

[37] Charles, J. C., Robert, B. Mabagala, Mnyuku, S. O. W. Reuben. (2013), Assessment of grain yield losses caused by rice blast disease in major rice growing areas in Tanzania. Inter. $J$. Scie. Res. 6, 14.

[38] Teng, P. S., Calvero, S. B., Torres, C. Q. (1989), The CERES-rice-blast simulation model. In: IBSNAT symposium: The decision support system for agro technology transfer. 